\title{
From EFL Teachers' Perspective: Impact of EFL Learners' Demotivation on Interactive Learning Situations at EFL Classroom Contexts
}

\author{
Amir Abdalla Minalla1,2 \\ ${ }^{1}$ Department of Languages and Translation, Faculty of Education and Arts, University of Taluk, Saudi Arabia \\ ${ }^{2}$ University College of Tayma, Saudi Arabia \\ Correspondence: Amir Abdalla Minalla, Department of Languages and Translation, Faculty of Education and Arts, \\ University of Taluk, Saudi Arabia \& University College of Tayma, Saudi Arabia.
}

Received: December 19, 2021

Accepted: January 21, 2022

Online Published: February 7, 2022

doi: 10.5539/elt.v15n3p1

URL: https://doi.org/10.5539/elt.v15n3p1

\begin{abstract}
For some reason, EFL students lose their motivation and interests and become more demotivated as time goes by. Many of the conducted studies focus on the factors that cause EFL learners' demotivation rather than how EFL learners' demotivation impact on classroom learning processes. Thus, the study will focus on the impact of EFL learners' demotivation on the procedures and processes employed for EFL classroom interaction. The data are collected and statistically analyzed. The findings revealed the processes and the procedures that adopted for developing classroom interaction are negatively affected by the low quality of the participation that EFL demotivators do. These results negatively reflected EFL classroom interaction processes, EFL teachers' performance, and EFL classroom group dynamics. In the light of these results, it recommended that the interactive classroom activities should be carefully designed and appropriately adapted to stimulate EFL demotivators' interests. For example, the characteristics of these interactive classroom activities are in their content that reflects EFL learners' cultural backgrounds and connects them to their every day actions.
\end{abstract}

Keywords: EFL demotivators, interaction, classroom, interactive, activities, classroom learning

\section{Introduction}

Learning a foreign language is not an easy task. One of the biggest EFL teachers' classroom challenges nowadays is EFL learners' lack of motivation and low interest towards learning English language as foreign language. Undoubtedly, well-motivated and interested students do their best in the classroom. They help teachers to do their best instructions and facilitate tasks that make classroom learning more effective. The studies conducted by Dornyei (1994, 2005, 2009); Dornyei et al. (2011); Gardner (2007); Lasagabaster et al. (2014) cited in Song et al. (2016) have shown that less motivated students are less likely to succeed in their L2. Song \& Kim (2016), added that motivation is a crucial factor in second language (L2) learning. It has been considered one of the factors with the greatest influence on an individual's success in L2 learning. Thus, attaining classroom interaction is usually influenced by the learners' interests and motivation towards learning. While teacher teaching performance positively and negatively are influenced by lack of EFL teachers' training and professional development and their satisfactions. Shah et al. (2013) state that classroom teaching is impacted by the lack of learners' motivation, and without any motivation nothing can be done properly is absolutely true. Since teaching is a profession, it requires genuinely motivated and appropriately dedicated teachers to carry out the teaching tasks and lead the learners to the right path- the path of success.

\section{Literature Review}

\subsection{Motivation Vs Demotivation as Factors in EFL Learning}

Motivation is one of the crucial internal factors influencing students' academic performance among various factors. It is considered as one of the major problems for EFL teachers not only in the Arab World but also elsewhere. Motivators take initiative, and actively achieve tasks for attaining better outcomes. Motivated people are energized and activated to the end of the task and moved to do something (Suslu, 2006; Ryan et al., 2000). 
On the other hand, demotivation defined by Dörnyei (2001) as "specific external forces that reduce or diminishes the motivational basis of a behavioural intention or an ongoing action". In this respect, demotivational force pushes in the opposite direction - pushing backwards of motivational force (Gerald and Stuart, 2019). While Zhang (2007) defined demotivation as a force that decreases students' energy that stimulating students to learn. Dörnyei et al. (2011) cited in Chen (2019) explained that demotivation, concerns various negative influences that cancel out existing motivation" and the 'demotivated' learner is described as someone who once was motivated his or her but has lost interest or commitment for some reasons. Unmotivated people who have lost impetus and inspiration to act (Suslu, 2006). Thus, the EFL demotivators have no keen interest to actively involve in classroom tasks particularly in their practical stages and their attitudes may not enhance interactive learning in EFL classroom.

\subsection{Influence of Demotivation on EFL Classroom Interaction}

EFL teachers in the Arab countries often complain low proficiency of their students and they claim that because of lack of interest in learning English as well (Shehdeh, 2010). Learners, who show no interest in classroom activities, usually underperform and underachieve. Such demotivated learners resist classroom participation and pose a serious challenge to teachers who aim at developing learners' interests in language learning, conducting interactive classes and achieving their lessons' aims (Shah et al., 2013). Therefore, uncommunicative and uncooperative learners will not help the teachers to fulfill their teaching goals. A number of the following authors confirm the above claim about the demotivators' attitude in classroom learning. Less motivated learners avoid participation in classroom activities, cheat more creatively than they learn, expect answers from the teachers and use go-betweens to confront their teachers $(\mathrm{Li}, 1994)$. It means that the role of the demotivators in the classroom learning processes is more dependent. Because motivated learners particularly those who have a positive attitude towards the target language taking responsibility of their own learning that help them become more autonomous (Holec, 1981). EFL learners' demotivation not only influence classroom learning but also teachers' teaching performance. Liton (2012) claimed that teachers believe that learners' lack of motivation is the crux of the problems which influence teachers' performances and learners' outcomes. In the study that has been conducted by Shotherah et al. (2013) reported that learners who lack motivation lead to various factors that cause teachers' frustration and impede classroom teaching. In addition, the study conducted by Fattash (2013) showed that demotivation leads to the stress, teacher burnout, lack of interest, lack of accomplishment, emotional exhaustion, dissatisfaction and consequently affect their performance and achievement.

\subsection{Demotivation in EFL Saudi Classrooms}

The issue of demotivation is related to teaching and learning foreign languages around the world. It is not a thing associated with a particular country. It is an EFL teachers' difficulties, not only in the Arab World or Kingdom of Saudi Arabian in particular but also elsewhere. However, context of this study is Saudi therefore; in this respect some conducted studies will be considered to reflect demotivation and its influence in Saudi classrooms' contexts. In the study conducted by Shah et al. (2013), it was shown that EFL teaching in the Saudi Arabian Context is challenged by the lack of learners' motivation which is negatively influenced the pedagogical processes. The factor that affects EFL teaching at Saudi Universities is that classroom teaching is impacted by various factors including lack of learners' motivation. Lack of Learners to motivation leads to various other factors which cause teacher' frustration and impede classroom teaching. The second study was investigated in this concern by Al-Khairy (2013) revealed that Saudi university undergraduates felt demotivated because of the factors which include textbooks; English faculty behaviors; peer pressure; teaching methods; insufficient use of modern teaching aids, difficult English vocabulary and grammar etc. In addition, the following studies prove the influence of demotivation towards learning English language as a foreign language among EFL Saudi learners, in spite of this phenomenon is variable. For example, Fareh (2010) cited in Alrabai (2016) reports that attitude toward English learning in the Saudi EFL context that most students are unmotivated and do not want to learn similarly. Liton (2012) cited in Shah et al. (2013) finds that Saudi EFL classes suffer from sheer lack of both intrinsic and extrinsic motivation. Khan (2011) asserts the above claims by stating that Saudi Arabian students are not properly motivated towards educational goals. However, exceptional cases exist.

\section{Methodology}

\subsection{Instruments of Data Collection}

The study employs an interview and questionnaire as tools for data collection. Data collection tools are designed to be applied subsequently. In other words, questions of the interview are firstly done and then the questionnaire's statements. 


\subsection{Procedures of Data Collection}

The researcher has a long practical teaching experiences as an EFL teacher, during his task in the EFL classrooms he was used to putting down notes concerning the EFL classroom interaction's challenges. These notes are finally put in their final draft as interview's questions and questionnaire's statements. However, purposefully, the information used in both the interview and questionnaire are limited to the academic year (2019-2020). During his classroom teaching processes, the researcher was continuously noting down classroom interactions problems. The collected items are checked in the first semester and rechecked in the second that applied on two English language classes that taught the same book (Elementary plus of Headway series) as university requirement course. Moreover, the students of these classes are from the same age and level of English. Finally, the validated items are put in their final draft to be conducted by the participants to attain the study's objective.

The interview has four questions which are crucial for conducting questionnaire's statements. These questions intend to check the number of EFL demotivators in EFL classrooms from EFL teachers' points of view as well as the impact of EFL demotivators on EFL teachers' performance and students' achievement. The questionnaire is mainly designed to investigate the effect of EFL learners' demotivation on the actions that are taken for classroom interaction. In addition, it reflects EFL classroom problems that result from EFL demotivtors.

\subsection{Participants}

EFL university instructors are employed to answer the interview's questions and answer questionnaire's statements. The study intends the total population of the participants but, those who are actually involved are nineteen Ph.D. holders and twenty three M.A. holders. All participants are teaching English as a foreign language at Tabuk university. The study covers the five university colleges as well as the main campus of the university. Most of the participants have a long teaching experience that shown below in Table 2.

It is worth mentioning that the English classes from which the questionnaire's items are pointed out and processed are the classes of the first year Saudi university students who with the same age and level of English. These classes are first year university classes (preparatory year) that intend to teach English as a university requirement course.

\section{Data Analysis}

Table 1. Participants distribution according to the qualification variable

\begin{tabular}{lll}
\hline Qualification & Frequency & Percentage \\
\hline Ph.D holders & 19 & $46.5 \%$ \\
M.A holders & 23 & $53.5 \%$ \\
Total & 42 & $100 \%$
\end{tabular}

The total number of teachers who participated in this study is 42 . Nineteen of the participants are Ph.D. holders, whereas twenty-three are M.A. holders. The M.A. holders represent the majority by $54.8 \%$ while the Ph.D. holders are $46.5 \%$.

Table 2. Participants distribution according to the years of experience variable

\begin{tabular}{lll}
\hline Years of experiences & Frequency & Percentage \\
\hline $1-9$ & 17 & $39.5 \%$ \\
$10-20$ & 19 & $44.2 \%$ \\
Above 20 & 7 & $16.3 \%$ \\
Total & 42 & $100 \%$
\end{tabular}

The results of the above Table 2 have shown that the majority of the EFL university instructors have been teaching English for more than 10 years represent $45.2 \%$ while those who spent less than 10 years represent $38.1 \%$ and only 7 of them had more than 20 years of the experience. It indicates that the responses are formed based on long experiences and good teaching backgrounds. So, the outcomes that can be drawn from their responses will be very important for forming appropriate recommendations for the problem of the study.

\section{Findings and Discussion}

Because the study is mainly investigated from EFL teachers' point of view, the most appropriate tools used in conducting are to ask them via the interview's and questionnaire's questions. In this respect, these tools are applied subsequently beginning with interview questions and then questionnaire's statements come after. Both tools i.e. interview and questionnaire are designed to investigate the impact of EFL demotivators while English 
classes' processes for the interaction have been taking place. Thus, EFL teachers of these classes intend to reflect their attitudes whether they serve positively or negatively.

\subsection{Interview}

Forty two of the EFL university instructors were interviewed; nineteen are Ph.D. holders and the other twenty-three are M.A. holders. The interviewees are the same participants who answered the questionnaire. There were four questions to be asked. The first question formed as a multiple-choice question. The options are suggested in the question are carefully designed to enable the participants of estimating the number of EFL demotivators in their own English classes. Scales that the question offered are: 'too many', 'many', 'few', 'a few' or 'none'. The other three questions are formed to be answered by 'yes or no'. The other three questions are formed to be answered by 'yes or no'. Moreover, the participants are recommended and encouraged to feel free if they would like to justify their answers or add any further clarification. Thus, the questions reflect EFL teachers' attitudes towards EFL demotivators inside classroom contexts while managing classroom interaction.

The result of the first question as they are displayed in Table 3 and Figure 1 showed no EFL classes without EFL demotivators. It means that all the participants confirm that there are EFL demotivators in their English classes regardless of how many.

Table 3. Participants distribution reflecting the number of EFL demotivators variable in the EFL classroom from EFL teachers' point of view

\begin{tabular}{|c|c|c|c|c|c|c|c|}
\hline NO. & Question & Analysis & Too many & Many & Few & A few & None \\
\hline \multirow[t]{2}{*}{1} & \multirow{2}{*}{$\begin{array}{l}\text { The number of EFL demotivators } \\
\text { in your own EFL classroom is. }\end{array}$} & Frequency & 2 & 17 & 16 & 7 & 0 \\
\hline & & Percentage & $4.8 \%$ & $40.5 \%$ & $38.1 \%$ & $16.7 \%$ & $0 \%$ \\
\hline
\end{tabular}

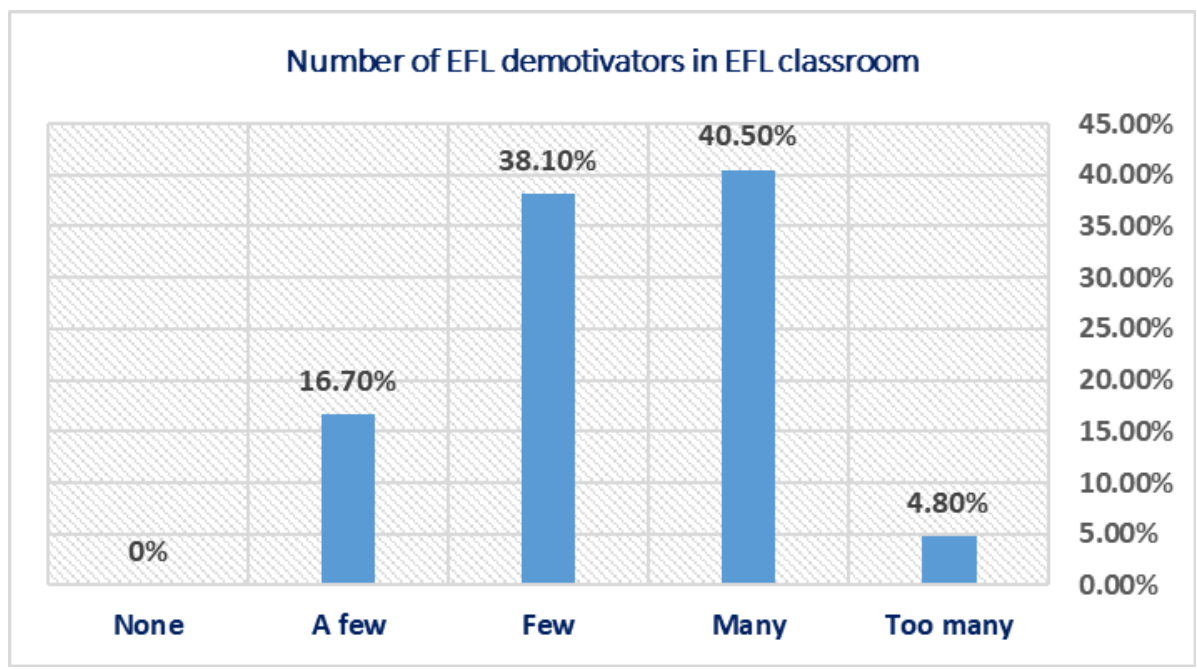

Figure 1. Shows number of EFL demotivators in the EFL classroom from EFL teachers' point of view

The majority (55\%) of the responses reported that the number of EFL demotivators in EFL classroom are few, as (38.1\%) of the respnese are for option 'few' and (16.7\%) for the option 'a few'. While (45\%) of the responses reflect that the number of demotivators in their EFL classroom is many distributed between (40.5\%) for the option 'many' and (4.8\%) for the option 'too many'. In spite of the majority of participants (55\%) said there are few numbers of EFL demotivators in their EFL classrooms but also (45\%) of the responses showed the number of EFL demotivators in EFL classroom is many that represents a considerable number compared to the total number of participants particularly the judgement was by EFL teachers. Both confirmed that there are EFL demotivators in their EFL classrooms. Undoubtedly, whether they are few or many, both affect classroom interactions and put challenges on EFL classroom learning processes that shown in the obtained results of the following analysis and discussion of the interview and questionnaire.

The second question placed number two in the Table 4 inquires the participants whether EFL demotivators affect classroom learning processes that are adopted for EFL classroom interaction. (95\%) of the participants positively confirm the claim of the question and the comments they presented to justify their answers can be summarized in the following points: weak engagement of the demotivators in building up effective classroom learning causes 
interruption towards establishing appropriate classroom interaction. On the other hand, the demotivators take no serious actions in order to play an effective role in interactive activities, as well as many of them avoid taking any part or doing a very limited one. Liton (2012) states that learners' lack of motivation is the crux of the problems which influence teachers' performances and learners' outcomes.

Table 4. Interview's questions show the influence of EFL demotivators on classroom learning processes

\begin{tabular}{llllll}
\hline NO. & Questions & Yes & & No & \\
\cline { 3 - 5 } & & Frequency & percentage & Frequency & percentage \\
\hline 2 & $\begin{array}{l}\text { Do EFL demotivators influence EFL } \\
\text { classroom interaction processes? }\end{array}$ & 40 & $95 \%$ & 2 & $5 \%$ \\
3 & $\begin{array}{l}\text { Are EFL classroom's group dynamics } \\
\text { degraded by EFL demotivators? }\end{array}$ & 42 & $100 \%$ & 0 & $0 \%$ \\
4 & $\begin{array}{l}\text { Do you think EFL demotivators } \\
\text { degrade teacher's motivation? }\end{array}$ & 32 & $76 \%$ & 10 & $24 \%$
\end{tabular}

The third question intends to identify that whether the classroom group dynamics are degraded by EFL demotivators. Accordingly, all the participants confirmed that EFL demotivators degrade the classroom group dynamics. The majority of participants $(70 \%)$ added comments on their provided answers which can be summarised in the following: EFL classroom's groups can not be efficient unless the majority of its members play an active role in their all actions. Learners, who show no interest in classroom activities, usually underperform and underachieve. Demotivation can negatively influence the learner's attitudes and behaviors, degrade classroom group dynamics, teacher's motivation, and result in long-term and widespread negative learning outcomes (Falout et al., 2009). Moreover, demotivators avoid participation in classroom activities (Shah et al., 2013; Li, 1998).

The fourth question inquires the participants whether the EFL demotivators could degrade the teacher's motivation. The participants' answers vary between (76\%) of them are 'yes' so positively supporting the claim of the question. While $(24 \%)$ of them are 'no' so they do not think that demotivators could degrade teachers' motivation. The participants justify their answers with that EFL demotivators' poor performance and interaction partially affect teacher's motivation and his performance as well. They added that EFL teachers become more familiar and well trained to deal with EFL demotivators' reactions. Shah et al. (2013) reported that learners lack of motivation leads to various other factors which cause teachers' frustration. In addition, the study that is conducted by Jahedizadeh et al. (2016) has shown that when emotionally exhausted teachers are not actively and enthusiastically involved in organizing classroom time and in devising tasks and activities. learners' lack of motivation influences teachers' performances and learners' outcomes (Liton, 2012; Fattash, 2013).

\subsection{Questionnaire Analysis}

The questionnaire's items are designed to investigate the problems caused by EFL learners' demotivation in implementing interactive learning in the classroom. These items reflect the classroom learning procedures that teachers usually take in developing classroom interaction. All the questionnaire's statements presented in Table 5 are conducted from EFL teachers' points of view as follows: 
Table 5. Shows the questionnaire's statements that are answered by EFL university instructors reflecting their points of view

\begin{tabular}{|c|c|c|c|c|c|c|c|}
\hline \multicolumn{2}{|c|}{ EFL demotivators ............... } & \multirow{2}{*}{$\begin{array}{l}\text { Analysis } \\
\text { Frequency }\end{array}$} & \multirow{2}{*}{$\begin{array}{l}\text { Strongly } \\
\text { agree }\end{array}$} & \multirow{2}{*}{$\begin{array}{l}\text { Agree } \\
27\end{array}$} & \multirow{2}{*}{$\begin{array}{l}\text { Neutral } \\
3\end{array}$} & \multirow{2}{*}{$\begin{array}{l}\text { Strongly } \\
\text { disagree }\end{array}$} & \multirow{2}{*}{$\begin{array}{l}\text { Disagree } \\
1\end{array}$} \\
\hline 1 & pay little attention to the classroom & & & & & & \\
\hline & instructions. & Percentage & $21 \%$ & $64 \%$ & $7 \%$ & $5 \%$ & $2 \%$ \\
\hline \multirow[t]{2}{*}{2} & \multirow{2}{*}{$\begin{array}{l}\text { ignore the necessary information for } \\
\text { completing interactive classroom tasks }\end{array}$} & Frequency & 8 & 28 & 5 & 0 & 2 \\
\hline & & Percentage & $19 \%$ & $67 \%$ & $10 \%$ & $0 \%$ & $4 \%$ \\
\hline \multirow[t]{2}{*}{3} & \multirow{2}{*}{$\begin{array}{l}\text { take no further steps towards } \\
\text { overcoming classroom-related learning } \\
\text { difficulties. }\end{array}$} & Frequency & 7 & 29 & 4 & 0 & 2 \\
\hline & & Percentage & $16 \%$ & $69 \%$ & $10 \%$ & $0 \%$ & $5 \%$ \\
\hline \multirow[t]{2}{*}{4} & \multirow{2}{*}{$\begin{array}{l}\text { are not encouraged to take part in extra } \\
\text { supportive activities. }\end{array}$} & Frequency & 4 & 31 & 2 & 2 & 3 \\
\hline & & Percentage & $10 \%$ & $73 \%$ & $5 \%$ & $5 \%$ & $7 \%$ \\
\hline \multirow[t]{2}{*}{5} & \multirow{2}{*}{$\begin{array}{l}\text { Lack interest in engaging in the } \\
\text { classroom interactive tasks. }\end{array}$} & Frequency & 7 & 29 & 0 & 2 & 4 \\
\hline & & Percentage & $17 \%$ & $69 \%$ & $0 \%$ & $4 \%$ & $10 \%$ \\
\hline \multirow[t]{2}{*}{6} & \multirow{2}{*}{$\begin{array}{l}\text { actively participate in the interactive } \\
\text { activities. }\end{array}$} & Frequency & 2 & 3 & 6 & 20 & 11 \\
\hline & & Percentage & $5 \%$ & $7 \%$ & $14 \%$ & $48 \%$ & $26 \%$ \\
\hline \multirow[t]{2}{*}{7} & \multirow{2}{*}{$\begin{array}{l}\text { fruitfully cooperate with their partners } \\
\text { in pair and group work tasks. }\end{array}$} & Frequency & 1 & 2 & 2 & 5 & 32 \\
\hline & & Percentage & $2 \%$ & $5 \%$ & $5 \%$ & $12 \%$ & $76 \%$ \\
\hline \multirow[t]{2}{*}{8} & \multirow{2}{*}{$\begin{array}{l}\text { take no initiative to share their learning } \\
\text { experiences inside classroom context. }\end{array}$} & Frequency & 8 & 31 & 0 & 3 & 0 \\
\hline & & Percentage & $19 \%$ & $73 \%$ & $0 \%$ & $7 \%$ & $0 \%$ \\
\hline \multirow[t]{2}{*}{9} & \multirow{2}{*}{$\begin{array}{l}\text { avoid taking parts in the activities that } \\
\text { intend to be achieved cooperatively }\end{array}$} & Frequency & 12 & 24 & 2 & 2 & 2 \\
\hline & & Percentage & $29 \%$ & $57 \%$ & $5 \%$ & $5 \%$ & $5 \%$ \\
\hline \multirow[t]{2}{*}{10} & \multirow{2}{*}{$\begin{array}{l}\text { cause delay for what is required to be } \\
\text { achieved. }\end{array}$} & Frequency & 10 & 25 & 3 & 3 & 1 \\
\hline & & Percentage & $24 \%$ & $60 \%$ & $7 \%$ & $7 \%$ & $2 \%$ \\
\hline
\end{tabular}

The learning difficulties that occur during classroom learning processes of learning a language have negatively reflected on students' outcomes. The results presented in Table 5 have shown that the difficulties and challenges that EFL demotivators cause inside EFL classroom contexts are due to ineffective actions that they adopt. The analysis of these results illustrated that the majority of the participants prove a positive attitude towards the statements' claims and support them as follows: The statistical results of the statement (1) report (85\%) of participants agreed upon that EFL demotivators pay little attention to the classroom instructions. EFL learners are prone to certain distractions during ongoing learning processes due to many factors related to the classroom contexts and others connected with outside classroom contexts. The performance of EFL learners inside classroom contexts mainly depends on understanding classroom's instructions i.e. what to do, when, and how to do something. Al'Omairi et al. (2015), stated that paying attention is an important factor contributing to learning because, it facilitates information processing and has a huge impact on students' immediate response in the classroom. Styles (1997) added that paying attention has an important role in the learning process because, it brings whatsoever information being discussed to consciousness and leads to conscious processing. Missing classroom instructions definitely affects classroom interaction processes and hinders learners' communication. Attracting great attention is one of the crucial factors for some classroom key learning points. Thus, good attention draws better expectations of classroom learning performance. Concerning statement (2), its claim is obviously supported by the majority of the participants i.e. (86\%) reflected that EFL demotivators ignore the necessary information for completing interactive classroom tasks. Missing key learning items discourage learners' participation, affects enhancement of classroom interaction and then, poor classroom interaction. The statistical results for the statement (3) have shown that (85\%) participants agree that EFL demotivators take no further steps towards overcoming classroom-related learning difficulties. Some of these difficulties that need keen interest and extra efforts inside and outside the classroom contexts are poor pronunciation, poor syntactic structures, mastering connected speech ......etc. Thus, without having practical actions to overcome such classroom learning difficulties there will be no better performance. In the fourth statement (83\%) of the participants said that demotivators are not encouraged to take part in the extra supportive activities. Classroom interaction inevitably needs more actions to be taken. For example, verbal interactive activities are needed for extra practices whether they are designed to be 
conducted inside and outside the classroom contexts. Lack of practice may lead to truncated production and poor classroom performance.

Interactive tasks become the main means for teachers and students to exchange their ideas, feelings, opinions, insights, etc. According, to the result of the statement (5) showed that (86\%) the participants support the claim that EFL demotivators lack interest in engaging in the classroom interactive tasks. One of the biggest challenges that EFL teachers encounter is the lack of students' interest to involve in classroom activities. Ainley et al. (2002); Hidi \& Renninger, (2006) cited in Jahedizadeh et al. (2016), stated that interest and joy towards some particular issue - classroom activities, for instance - promote attention, recall, effort, and achievement. Hidi (1990) cited in Jahedizadeh et al. (2016) said that the fact that being interested in a topic dramatically contributes to better achievement and performance is undeniable. Therefore, weak or lack of classroom participation in the interactive activities affect achieving classroom learning and complicating the teachers' tasks of doing so. Maharantau (2015) points out that students have shown that bad attitude in the classroom i.e. show no interest in teaching-learning processes by doing useless activities.

Consequently, the result of the statement (6) has shown that (74\%) the participants disagree that EFL demotivators actively participate in the classroom discussion. Such demotivated learners resist classroom participation and pose a serious challenge to their teachers those who aim at developing learners' interests in language learning (Shah et al., 2013). Less motivated learners avoid participation in classroom activities ( $\mathrm{Li}, 1994)$. According to the result of the statement (7) has shown that (88\%) the participants disagree that EFL demotivators fruitfully cooperate with their partners in pair and group work tasks. So, it means that the demotivators play no effective role when they involve in collaborative and cooperative activities. Less motivated learners cheat more creatively than they learn (Li, 1994). Whole interactive learning processes tend to depend on collaborative and cooperative activities that are designed for sharing and exchanging thoughts. Thus, the lack of interest that EFL demotivators show in the pair and group work tasks reflected on the processes of classroom interactions.

Interested or motivated students who usually take initiative in a classroom discussion and overcome EFL classroom learning's challenges. Some interactive activities arouse the students taking initiative for classroom discussion. The result of the statement (8) has shown the majority of the participants (92\%) agree that EFL demotivators take no initiative to share their learning experiences inside classroom context. Thus, it proved in the statement (5) and statement (7) EFL demotivators lack interest in engaging in classroom discussion, and they do not cooperate with their partners in pair and group work tasks. Consequently, the result of the statement (9) showed that (86\%) the EFL demotivators avoid taking parts in activities that intend to be carried out cooperatively. Not all the classroom learning activities are conventional structured, some of them are voluntarily initiated by the learners. Gorham et al. (1997) and Zhang (2007) cited in Jahedizadeh et al. (2016) pointed out that the EFL demotivators related to exam focused lessons and emphasizes on memorization of language. Statistical result of the statement (10) reported that $(84 \%)$ the participants agree that EFL deomtivators cause delay for what is required to be achieved. Thus, that is supported by the result of the statements (5) and the statement (6) that EFL demotivators lack interest in engaging and do not actively participate in the interactive activities.

\section{Conclusion}

Although the great efforts that EFL teachers made and effective techniques they employ still EFL demotivators represent their big challenges in establishing effective classroom interaction. The study mainly focuses on the EFL demotivators' impact in implementing classroom interactive activities. The findings have revealed that classroom-learning processes are negatively affected by EFL demotivators' actions and reactions that taken in the classroom interaction processes. Thus, these actions and reactions impact on EFL teachers' motivation, EFL classroom group dynamics, and classroom learning processes.

Depending on these results, the study recommends that classroom learning activities need to be adapted to arouse EFL demotivators' interests. For example, these activities and tasks are to be characterized by their content and language items that made them up of such as they match EFL demotivators' language levels, reflect their cultural backgrounds, enable them to express their own interests, can be achieved individually, related to their every day actions.....etc.

\section{References}

Ainley, M., Hidi, S., \& Berndorff, D. (2002). Interest, learning, and the psychological processes that mediate their $\begin{array}{llll}\text { relationship. Journal of Educational Psychology, 94(3), 545-561. } & \text {. }\end{array}$ https://doi.org/10.1037/0022-0663.94.3.545

Al'Omairi, T., \& Al Balushi, H. (2015). The Influence of Paying Attention in Classroom on Students' Academic Achievement in Terms of their Comprehension and Recall Ability. 2-4 February 2015- Istanbul, Turkey, Proceedings of INTCESS15- 2nd International Conference on Education and Social Sciences. 
Al-Khairy, M. (2013). English as a foreign language learning Demotivational factors as perceived by Saudi undergraduates. European Scientific Journal, 9(32).

Alrabai, F. (2016). Factors Underlying Low Achievement of Saudi EFL Learners. International Journal of English Linguistics, 6(3). https://doi.org/10.5539/ijel.v6n3p21

Chen, C. (2019). Study on Learners' Demotivation in EFL Classroom - A Case Study at a Higher Vocational College. Education Journal, 8(6), 338-343. https://doi.org/10.11648/j.edu.20190806.25

Dörnyei, Z., \& Ushioda, E. (2011). Teaching and Researching Motivation (2nd ed.). Harlow, England: Pearson Education.

Dörnyei, Z. (2001). Teaching and researching motivation.

Falout, J., Elwood, J., \& Hood, M. (2009). Demotivation: Affective states and learning outcomes. System, 37(3), 403-417. https://doi.org/10.1016/j.system.2009.03.004

Fattash, M. (2013). Demotivating Factors of University ESL Teachers. International Journal of Humanities and Social Science, 3(19).

Gerald, H., \& Stuart, R. (2019). Demotivation as a Factor in the Performance of EFL Teachers in the Catholic University of Santiago de Guayaquil, Ecuador. Revista ESPACIOS, 40(19).

Hidi, S. (1990). Interest and its contribution as a mental resource for learning. Review of Educational Research, 60(4), 549-571. https://doi.org/10.3102/00346543060004549

Hidi, S., \& Renninger, K. A. (2006). The four-phase model of interest development. Educational Psychologist, 4l(2), 111-127. https://doi.org/10.1207/s15326985ep4102_4

Jahedizadeh, S., Ghanizadeh, A., \& Ghonsooly, B. (2016). The role of EFL learners' demotivation, perceptions of classroom activities, and mastery goal in predicting their language achievement and burnout. Asian-Pacific Journal of Second and Foreign Language Education, 1. https://doi.org/10.1186/s40862-016-0021-8

Khan, I. (2011). An Analysis of Learning Barriers: The Saudi Arabian Context. International Education Studies, 4(1). https://doi.org/10.5539/ies.v4n1p242

Khan, I. A. (2011). Learning difficulties in English: Diagnosis and pedagogy in Saudi Arabia. International Research Journals, 2(7), 1248-1257.

Li, D. (1998). "It's always more difficult than you plan and imagine": Teachers' perceived difficulties in introducing the communicative approach in South Korea. TESOL Quarterly, 32(4), 677-703. https://doi.org/10.2307/3588000

Liton, H. A. (2012). Developing EFL Teaching and Learning Practices in Saudi Colleges: A Review. International Journal of Instruction, 5(2), 129-152.

Ryan Richard, M., \& Edward L. Deci. (2000). Intrinsic and extrinsic motivations: Classic definitions and new directions. Contemporary Educational Psychology, 25(1), 54-67. https://doi.org/10.1006/ceps.1999.1020

Shah, S., Hussain, M., \& Nasseef, O. (2013). Factors Impacting EFL Teaching: An Exploratory Study in the Saudi Arabian Context. Arab World English Journal, 4(3), 104-123.

Shehdeh, F. (2010). Challenges of teaching English in the Arab world: Why can't EFL programs deliver as expected? Procedia - Social and Behavioral Sciences, 2(2), 3600-3604. https://doi.org/10.1016/j.sbspro.2010.03.559

Song, B., \& Kim, T.-Y. (2016). The dynamics of demotivation and remotivation among Korean high school EFL students. System, 65, 90-103. https://doi.org/10.1016/j.system.2016.12.010

Styles, E. (1997). The psychology of attention. UK: Psychology Press Ltd.

Suslu, S. (2006). Motivation of ESL teachers. The Intenet TESL Journal, XII.

Zhang, Q. (2007). Teacher misbehaviors as learning demotivators in college classrooms: A cross-cultural investigation in China, Germany, Japan, and the United States. Communication Education, 56(2), 209-227. https://doi.org/10.1080/03634520601110104

\section{Copyrights}

Copyright for this article is retained by the author(s), with first publication rights granted to the journal.

This is an open-access article distributed under the terms and conditions of the Creative Commons Attribution license (http://creativecommons.org/licenses/by/4.0/). 